\title{
Dinamika Nitrogen dan Hasil Tanaman Padi Sawah (Oryza sativa L.) Kultivar INPARI 31 akibat Pemupukan NPK 18:8:18 dan Penggenangan Air pada Fluvaquentic Epiaquepts
}

\author{
Rija Sudirja1, Hidayat Salim¹, Ade Setiawan dan Muhammad Farghan Fauzan² \\ ${ }^{1}$ Staff Pengajar Departemen Ilmu Tanah dan Sumberdaya Lahan Fakultas Pertanian \\ Universitas Padjadjaran \\ ${ }^{2}$ Alumni Program Magister Ilmu Tanah, Fakultas Pertanian Universitas Padjadjaran \\ Jl. Raya Bandung Sumedang Km 21 Jatinangor \\ Korespondensi: rija.sudirja@unpad.ac.id
}

\begin{abstract}
Fertilizer is one of the crucial means to improving rice productivity. The purpose of this research is to know and understand the behavior of nitrogen in the soil and plant rice (Oryza sativa L.) as well as the highest yields in Fluvaquentic Epiaquepts. This study was conducted in May through September 2015 at the Experimental Garden of Soil and Water Management, Faculty of Agriculture Padjadjaran University, Jatinangor, Sumedang regency. The altitude of place was 725 meters above sea level. The study design used randomized block design (RAK) with ten treatments, various dosage level of NPK 18:8:18 combined with the setting puddles and three replications, thus totaling thirty experimental plots. The results showed a real effect due to the provision of various level dose of NPK 18:8:18 and combinations of settings puddles on plant growth, the content of soil$N$, absorption- $N$, and rice yields, both at the time of vegetative end as well as post-harvest rice. In addition, treatment of NPK 18:8:18 by setting a puddle able to deliver the highest yield at the time of post-harvest each by $\mathrm{N}$-total of 0,64\%; $\mathrm{N}$-organic 0,26\%; $\mathrm{N}-\mathrm{NH}_{4} \quad 0,11 \%$; $\mathrm{N}-\mathrm{NO}_{3} \mathrm{0,31 \%}$; and absorption- $N$ of plants by 1,80\%. This resulted in a relatively high yield of $9.952 \mathrm{~kg}^{\circ} \mathrm{ha}^{-1}$, but not significantly different from NPK doses of 450 and $600 \mathrm{~kg} \cdot \mathrm{ha}^{-1}$.
\end{abstract}

Keywords: NPK doses, soil- $N$, absorption- $N$, rice yield

\section{PENDAHULUAN}

Tanah sawah umumnya diperuntukan untuk budidaya padi sawah, baik terusmenerus sepanjang tahun maupun bergiliran dengan tanaman palawija. Sifat tanah sawah sangat beragam sesuai dengan sifat tanah asalnya. Tanah daerah penelitian, menurut Arifin (2000) termasuk sub grup Fluvaquentic Epiaquepts, memiliki sifat fluvial dengan kondisi dominan akuik (jenuh air pada satu atau lebih horizon), dan adanya reaksi reduksi secara periodik pada solum tanah, sehingga ditemukan adanya episaturasi (penjenuhan atas). Selain itu, tanah ini memiliki kandungan sifat kimia yang miskin unsur hara, diantaranya $\mathrm{pH}$ 5,88 (agak masam), $\mathrm{N}$-total $\quad 0,28 \%$ (sedang), $\mathrm{P}_{2} \mathrm{O}_{5}$ Potensial 11,51 (sangat rendah), dan $\mathrm{K}_{2} \mathrm{O}$ Potensial (sedang).
Usahatani pada tanah-tanah sawah Fluvaquentic Epiaquepts perlu memperhatikan pasokan unsur hara agar dapat meningkatkan produktivitas tanaman. Salah satu upaya untuk memperbaiki sifat kimia yang terkandung dalam tanah Fluvaquentic Epiaquepts yaitu dengan cara pemberian pupuk NPK 18:8:18. Sejalan hasil penelitian Sutejo (2002), bahwa pemberian pupuk NPK ke dalam tanah dapat menambah ketersediaan hara yang cepat bagi tanaman. Penggunaan pupuk NPK dapat menjadi solusi dalam meningkatkan ketahanan dan keamanan pangan. Pupuk majemuk merupakan pupuk campuran yang umumnya mengandung lebih dari satu macam unsur hara tanaman (makro maupun mikro) terutama $\mathrm{N}, \mathrm{P}$ dan $\mathrm{K}$ (Rosmarkam dan Yuwono, 2002). 
Pupuk NPK 18:8:18 bentuk granular dapat berfungsi sebagai pelepas lambat (slow release), tidak mudah larut dan tercuci, sehingga diharapkan dapat meningkatkan efisiensi pemupukan. Nitrogen merupakan salah satu unsur hara yang sangat diperlukan oleh tanaman padi, khususnya pada saat pertumbuhan vegetatif. Pemupukan $\mathrm{N}$ harus diperhatikan mengingat efisiensi $\mathrm{N}$ yang sangat rendah (Mulyani, 1999; Suyono, 2008).

Absorpsi nitrogen oleh tanaman dipengaruhi oleh factor-faktor lingkungan, seperti suhu tanah, suhu udara, aerasi, $\mathrm{pH}$, komposisi unsur lain, cekaman air, dan spesies tanaman itu sendiri (Foth, 1994; Mulyani, 1999). Bentuk N-nitrat $\left(\mathrm{NO}_{3}{ }^{-}\right)$ biasanya lebih mudah bergerak ke akar tanaman melalui difusi dan aliran massa dibandingkan dengan $\mathrm{NH}_{4}{ }^{+}$. Banyaknya $\mathrm{NH}_{4}{ }^{+}$ dan $\mathrm{NO}_{3}{ }^{-}$yang tersedia bagi tanaman tergantung pada pemupukan dan mineralisasi bahan organik tanah (Tisdale et al., 1993). Tujuan penelitian ini yaitu untuk mengetahui dan memahami perilaku nitrogen dalam tanah dan tanaman padi sawah (Oryza sativa L.) serta hasil panen akibat pemberian kombinasi dosis NPK 18:8:18 dengan pengaturan air pada tanah sawah sub grup Fluvaquentic Epiaquepts.

\section{METODE PENELITIAN}

Penelitian ini dilaksanakan di Kebun Percobaan Pengelolaan Tanah dan Air Fakultas Pertanian Unpad, Jatinangor, Sumedang. Terletak pada ketinggian 725 meter di atas permukaan laut dengan tipe curah hujan C berdasarkan Schmidt dan Fergusson (1951), dengan rata-rata curah hujan $2179 \mathrm{~mm}$ per tahun. Penelitian ini dikakukan dari bulan Februari 2015 sampai dengan bulan Mei 2015 .

Bahan yang digunakan dalam percobaan terdiri dari: (1) Tanah Fluvaquentic Epiaquepts asal Jatinangor, (2) Benih padi Varietas INPARI 31, (3) Pupuk Majemuk NPK 18:8:18 produksi PT. Pupuk Kaltim.

Alat yang digunakan dalam percobaan terdiri dari: (1) Peralatan laboratorium untuk analisis tanah dan tanaman, (2) Peralatan lapangan: cangkul, garu, caplak, sprayer, timbangan teknis, gunting, penggaris, meteran kain, tali rapia, alat tulis dan catatan harian pengamatan, dan (3) Satu unit komputer sebagai alat untuk mengolah data.

Percobaan menggunakan metode eksperimen Rancangan Acak Kelompok (RAK) dengan 10 perlakuan (Tabel 1) dengan 3 kali ulangan, sehingga total perlakuan berjumlah 30 petak percobaan, masing-masing berukuran $2 \mathrm{~m}$ x $3 \mathrm{~m}$.

Tabel 1 Kombinasi perlakuan pemberian dosis pupuk NPK dengan pengaturan genangan air terhadap padi kultivar INPARI 31

\begin{tabular}{ccc}
\hline Perlakuan & $\begin{array}{c}\text { NPK } \\
\left({\left.\mathrm{kg} . h \mathrm{~A}^{-1}\right)}^{-}\right.\end{array}$ & Tinggi Genangan Air \\
\hline $\left.\mathrm{A}^{*}\right)$ & 0 & $5 \mathrm{~cm}$ \\
B & 150 & $5 \mathrm{~cm}$ \\
C & 300 & $5 \mathrm{~cm}$ \\
D & 450 & $5 \mathrm{~cm}$ \\
E & 600 & $5 \mathrm{~cm}$ \\
F & 750 & $5 \mathrm{~cm}$ \\
G & $\left.{ }^{* *}\right)$ & $5 \mathrm{~cm}$ \\
H & 450 & macak-macak \\
I & 450 & pengairan selang 1 hari \\
& & sampai macak-macak \\
J & 450 & pengairan selang 3 hari \\
& & sampai macak-macak \\
\hline
\end{tabular}

Keterangan:

a) ${ }^{*}$ Kontrol adalah perlakuan tanpa NPK.

b) Konversi dari kg.ha-1 ke g/petak terdapat pada Lampiran 5.

c) $\left.{ }^{* *}\right)$, dosis anjuran setempat. $200 \mathrm{~kg}^{\text {Urea ha-1, } 75}$ $\mathrm{kg} \mathrm{ha}^{-1}, 50 \mathrm{~kg} \mathrm{ha}^{-1}$.

d) Dosis level 450 kg.ha-1 atau 81 kg.ha-1 $\mathrm{N}$ sebagai level tengah yang diambil dengan perhitungan kesetaraan pupuk N-urea yang lazim digunakan sebanyak $200 \mathrm{~kg} \mathrm{ha}^{-1}$ atau 92 kg.ha-1.

\section{HASIL DAN PEMBAHASAN}

\subsection{Dinamika Nitrogen pada Tanah Saat Vegetatif Maksimum}

Hasil penelitian menunjukkan bahwa pemupukan $750 \mathrm{~kg} \mathrm{NPK} \mathrm{ha}^{-1}(\mathrm{~F})$ berpengaruh nyata terhadap kandungan $\mathrm{N}$-total tanah, penambahan berbagai taraf dosis NPK mampu memberikan pengaruh nyata terhadap N-total tanah (Tabel 2). 
Tabel 2 Pengaruh kombinasi dosis NPK dan genangan air terhadap N-total, N-organik, N-NH, $\mathrm{N}$ $\mathrm{NO}_{3}$ tanah pada saat vegetatif maksimum

\begin{tabular}{|c|c|c|c|c|c|}
\hline \multirow{2}{*}{\multicolumn{2}{|c|}{ Perlakuan }} & N-total & N-organik & $\mathrm{N}-\mathrm{NH}_{4}$ & $\mathrm{~N}-\mathrm{NO}_{3}$ \\
\hline & & \multicolumn{4}{|c|}{ 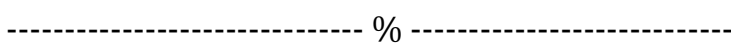 } \\
\hline & tanpa pupuk, digenangi $5 \mathrm{~cm}$ (kontrol) & $0,20 \mathrm{c}$ & $0,02 \mathrm{a}$ & $0,03 \mathrm{a}$ & $0,26 \mathrm{a}$ \\
\hline B & $150 \mathrm{~kg} \mathrm{NPK} \mathrm{ha-1}$, digenangi $5 \mathrm{~cm}$ & $0,20 \mathrm{c}$ & $0,03 \mathrm{bc}$ & $0,04 \mathrm{ab}$ & $0,27 \mathrm{~b}$ \\
\hline $\mathrm{C}$ & $300 \mathrm{~kg} \mathrm{NPK} \mathrm{ha}^{-1}$, digenangi $5 \mathrm{~cm}$ & $0,19 \mathrm{bc}$ & $0,03 \mathrm{bc}$ & $0,05 \mathrm{bc}$ & $0,28 \mathrm{bc}$ \\
\hline $\mathrm{D}$ & $450 \mathrm{~kg} \mathrm{NPK} \mathrm{ha}^{-1}$, digenangi $5 \mathrm{~cm}$ & $0,18 \mathrm{abc}$ & $0,04 \mathrm{~d}$ & 0,07 de & 0,29 def \\
\hline $\mathrm{E}$ & $600 \mathrm{~kg}$ NPK ha-1, digenangi $5 \mathrm{~cm}$ & $0,17 \mathrm{ab}$ & $0,05 \mathrm{e}$ & 0,08 ef & 0,30 ef \\
\hline $\mathrm{F}$ & $750 \mathrm{~kg}$ NPK ha-1, digenangi $5 \mathrm{~cm}$ & $0,16 \mathrm{a}$ & $0,06 \mathrm{e}$ & $0,09 \mathrm{f}$ & $0,31 \mathrm{f}$ \\
\hline G & $\begin{array}{l}\text { Anjuran Setempat: } 200 \mathrm{~kg} \text { Urea ha-1, } 75 \mathrm{~kg} \mathrm{ha}^{-1} \text {, } \\
50 \mathrm{~kg} \mathrm{ha}^{-1} \text {, digenangi } 5 \mathrm{~cm}\end{array}$ & $0,19 \mathrm{bc}$ & $0,04 \mathrm{~cd}$ & $0,07 \mathrm{de}$ & 0,30 ef \\
\hline $\mathrm{H}$ & $\begin{array}{l}450 \mathrm{~kg} \text { NPK ha-1 dengan pengairan macak- } \\
\text { macak }\end{array}$ & $0,20 \mathrm{c}$ & $0,03 \mathrm{ab}$ & $0,06 \mathrm{~cd}$ & 0,29 cde \\
\hline I & $\begin{array}{l}450 \text { kg NPK ha-1 dengan pengairan selang } 1 \\
\text { hari sampai macak-macak }\end{array}$ & $0,19 \mathrm{bc}$ & $0,02 \mathrm{ab}$ & $0,07 \mathrm{de}$ & $0,28 \mathrm{bcd}$ \\
\hline & $\begin{array}{l}450 \text { kg NPK ha-1 dengan pengairan selang } 3 \\
\text { hari sampai macak-macak }\end{array}$ & $0,19 \mathrm{bc}$ & $0,02 a b$ & $0,06 \mathrm{~cd}$ & $0,28 \mathrm{bcd}$ \\
\hline
\end{tabular}

Keterangan: Angka-angka yang diikuti huruf yang sama tidak berbeda nyata menurut uji jarak berganda Duncan $5 \%$

Dosis NPK yang paling tinggi $750 \mathrm{~kg} \mathrm{ha}^{-1}$ berpengaruh nyata dari taraf dosis yang lainnya.Peningkatan mulai dari $600 \mathrm{~kg}$ ha${ }^{1}$ dengan perlakuan digenangi memberikan pengaruh yang signifikan terhadap $\mathrm{N}$-total tanah, akan tetapi dosis $450 \mathrm{~kg} \mathrm{ha}^{-1}$ mulai dari perlakuan macak-macak sampai dengan penggenangan selang satu hari dan tiga hari tidak memberikan pengaruh yang signifikan. Hal ini diperkuat dengan pendapat Winarso (2005). Pemberian pupuk NPK berakibat kepada fluktuasi kandungan $\mathrm{N}$ dalam tanah, hal ini terjadi karena $\mathrm{N}$ dalam tanah berkesetimbangan antara bentuk yang satu dengan yang lainnya.

Tidak terdapat pengaruh yang signifikan dari berbagai taraf dosis NPK dan penggenangan terhadap N-organik tanah, hal ini diduga $\mathrm{N}$-organik dalam tanah menstimulasi proses amonifikasi dan nitrifikasi yang menghasilkan terbentuknya $\mathrm{NH}_{4}{ }^{+}$dan $\mathrm{NO}_{3}$. Sejalan dengan pengukuran potensi redoks pada tanah tergenang menunjukkan suasana reduksi, sedangkan pada kondisi macakmacak menunjukkan kondisi oksidasi.

Hasil penelitian menunjukkan bahwa pemupukan $750 \mathrm{~kg} \mathrm{NPK} \mathrm{ha}^{-1}(\mathrm{~F})$ berpengaruh nyata terhadap kandungan $\mathrm{N}-\mathrm{NH}_{4}$ tanah, penambahan berbagai taraf dosis NPK mampu memberikan pengaruh nyata terhadap $\mathrm{N}-\mathrm{NH}_{4}$ tanah. Jumlah $\mathrm{NH}_{4}{ }^{+}$akan meningkatkan pertumbuhan vegetatif, karena $\mathrm{NH}_{4}{ }^{+}$dapat terionisasi dan langsung dimanfaatkan oleh tanaman. Kandungan N$\mathrm{NH}_{4}$ dipengaruhi oleh taraf dosis pemupukan NPK, mekanismenya proses amonifikasi yang menyediakan $\mathrm{NH}_{4}{ }^{+}$yang didukung oleh $\mathrm{pH}$ netral (Rosmarkam dan Yuwono, 2002).

Hasil penelitian menunjukkan bahwa pemupukan $750 \mathrm{~kg} \mathrm{NPK} \mathrm{ha-1} \mathrm{(F)} \mathrm{berpengaruh}$ nyata terhadap kandungan $\mathrm{N}^{-\mathrm{NO}_{3}}$ tanah, penambahan berbagai taraf dosis NPK mampu memberikan pengaruh nyata terhadap $\mathrm{N}-\mathrm{NO}_{3}$ tanah. $\mathrm{NO}_{3}-$ diambil sebagian besar tanaman, karena $\mathrm{NO}_{3}^{-}$lebih besar dibandingkan dengan $\mathrm{NH}_{4}{ }^{+}$, selain itu nitrat bebas bergerak ke perakaran melalui mekanisme aliran massa dan difusi.Lapisan atas dimana oksigen masih cukup, proses nitrifikasi akan menghasilkan $\mathrm{NO}_{3}$ (Havlin, et. al., 2005). Dalam hal ini selain proses pemupukan, berperan juga proses penambahan air irigasi. Air irigasi dapat mensuplai $\mathrm{N}-\mathrm{NO}_{3}$ sampai 9,94 ppm ke dalam 
tanah. Hal ini sejalan dengan Triyono (2013) dimana konsentrasi nitrat $\left(\mathrm{NO}_{3}{ }^{-}\right)$pada kedalaman $0-20 \mathrm{~cm}$ berkisar antara 1,86 ppm $-9,63 \mathrm{ppm}$.

\subsection{Kandungan Residu Nitrogen dalam Tanah setelah Panen}

Hasil penelitian menunjukkan bahwa pemupukan $750 \mathrm{~kg} \mathrm{NPK} \mathrm{ha-1} \mathrm{(F)} \mathrm{berpengaruh}$ nyata terhadap kandungan residu $\mathrm{N}$-total tanah, penambahan berbagai taraf dosis NPK mampu memberikan pengaruh nyata terhadap residu N-total tanah (Tabel 3). Kandungan $\mathrm{N}$-total tanah terendah terdapat pada perlakuan tanpa pupuk NPK (A), hal ini dikarenakan tidak adanya pasokan unsur hara tambahan yang diberikan ke dalam tanah tersebut. Residu N-total tanah mengindikasikan kandungan nitrogen yang masih tersimpan dalam tanah setelah tanaman diatasnya dipanen.

Tabel 3 Pengaruh kombinasi dosis NPK dan pengaturan genangan air terhadap residu N-total, $\mathrm{N}$-organik, $\mathrm{N}-\mathrm{NH}_{4}$, dan $\mathrm{N}-\mathrm{NO}_{3}$ tanah

\begin{tabular}{|c|c|c|c|c|c|}
\hline \multirow{2}{*}{\multicolumn{2}{|c|}{ Perlakuan }} & N-total & N-organik & $\mathrm{N}-\mathrm{NH}_{4}$ & $\mathrm{~N}-\mathrm{NO}_{3}$ \\
\hline & & \multicolumn{4}{|c|}{ - } \\
\hline A & Tanpa pupuk, digenangi $5 \mathrm{~cm}$ (kontrol) & $0,22 \mathrm{a}$ & $0,04 \mathrm{a}$ & $0.13 \mathrm{a}$ & $0,39 \mathrm{a}$ \\
\hline B & $150 \mathrm{~kg} \mathrm{NPK} \mathrm{ha}^{-1}$, digenangi $5 \mathrm{~cm}$ & $0,22 \mathrm{a}$ & $0,06 \mathrm{ab}$ & $0.16 \mathrm{abc}$ & $0,44 \mathrm{ab}$ \\
\hline $\mathrm{C}$ & $300 \mathrm{~kg} \mathrm{NPK} \mathrm{ha}^{-1}$, digenangi $5 \mathrm{~cm}$ & $0,24 \mathrm{a}$ & $0,06 \mathrm{ab}$ & $0.19 \mathrm{abc}$ & $0,49 \mathrm{bc}$ \\
\hline $\mathrm{D}$ & $450 \mathrm{~kg} \mathrm{NPK} \mathrm{ha}^{-1}$, digenangi $5 \mathrm{~cm}$ & $0,23 \mathrm{a}$ & $0,07 \mathrm{~b}$ & $0.22 \mathrm{bcd}$ & 0,52 cde \\
\hline $\mathrm{E}$ & $600 \mathrm{~kg} \mathrm{NPK} \mathrm{ha}^{-1}$, digenangi $5 \mathrm{~cm}$ & $0,24 \mathrm{a}$ & $0,08 \mathrm{~b}$ & $0.27 \mathrm{de}$ & 0,59 ef \\
\hline $\mathrm{F}$ & $750 \mathrm{~kg} \mathrm{NPK} \mathrm{ha}^{-1}$, digenangi $5 \mathrm{~cm}$ & $0,26 \mathrm{a}$ & $0,11 \mathrm{c}$ & $0.31 \mathrm{e}$ & $0,64 \mathrm{f}$ \\
\hline G & $\begin{array}{l}\text { Anjuran Setempat: } 200 \mathrm{~kg} \text { Urea ha- }{ }^{-1}, 75 \mathrm{~kg} \\
\mathrm{ha}^{-1}, 50 \mathrm{~kg} \mathrm{ha}^{-1} \text {, digenangi } 5 \mathrm{~cm}\end{array}$ & $0,22 \mathrm{a}$ & $0,07 \mathrm{~b}$ & $0.23 \mathrm{~cd}$ & 0,56 de \\
\hline $\mathrm{H}$ & $\begin{array}{l}450 \mathrm{~kg} \mathrm{NPK} \mathrm{ha}^{-1} \text { dengan pengairan macak- } \\
\text { macak }\end{array}$ & $0,24 \mathrm{a}$ & $0,07 \mathrm{~b}$ & $0.21 \mathrm{bcd}$ & 0,52 cde \\
\hline I & $\begin{array}{l}450 \mathrm{~kg} \mathrm{NPK} \mathrm{ha}^{-1} \text { dengan pengairan selang } 1 \\
\text { hari sampai macak-macak }\end{array}$ & $0,24 \mathrm{a}$ & $0,06 \mathrm{ab}$ & $0.19 \mathrm{abc}$ & $0,49 \mathrm{bcd}$ \\
\hline $\mathrm{J}$ & $\begin{array}{l}450 \mathrm{~kg} \mathrm{NPK} \mathrm{ha}^{-1} \text { dengan pengairan selang } 3 \\
\text { hari sampai macak-macak }\end{array}$ & $0,24 \mathrm{a}$ & $0,06 \mathrm{ab}$ & $0.15 \mathrm{ab}$ & $0,44 \mathrm{ab}$ \\
\hline
\end{tabular}

Keterangan: Angka-angka yang diikuti huruf yang sama tidak berbeda nyata menurut uji jarak berganda Duncan $5 \%$

Pemberian pupuk dengan berbagai dosis mulai dari 150, 300, 450, 600, 750 NPK kg.ha1 memberikan residu $\mathrm{N}$-total di dalam tanah secara beragam.Semakin tinggi dosis yang diberikan maka pengaruhnya semakin signifikan terhadap ketersediaan nitrogen di dalam tanah.

Hasil penelitian menunjukkan bahwa pemberian NPK tidak berpengaruh nyata pada N-organik tanah. Penambahan berbagai taraf dosis NPK tidak mampu memberikan pengaruh yang signifikan terhadap $\mathrm{N}$-organik tanah. Hal ini diduga N-organik tanah yang dihasilkan dari penambahan pupuk NPK, bahan organik tanah maupun fiksasi $\mathrm{N}$ oleh mikroba tanah dan hanya sebagian kecil berupa $\mathrm{N}$-anorganik yaitu $\mathrm{NH}_{4}{ }^{+}$dan $\mathrm{NO}_{3}$.
Pada tanah tergenang, $\mathrm{N}$ merupakan hara yang tidak stabil karena adanya proses mineralisasi bahan organik (amonifikasi, nitrifikasi, dan denitrifikasi) oleh mikroba tanah tertentu. Proses terbentuknya $\mathrm{NH}_{4}{ }^{+}$ oleh pemberian pupuk NPK memberikan pengaruh nyata, dan penambahan berbagai taraf dosis NPK mampu memberikan pengaruh yang signifikan terhadap residu $\mathrm{N}$ $\mathrm{NH}_{4}$ tanah.

Hasil penelitian juga menunjukkan bahwa pemupukan $750 \mathrm{~kg}$ NPK ha-1 (F) berpengaruh nyata terhadap kandungan $\mathrm{N}$ $\mathrm{NO}_{3}$ tanah, penambahan berbagai taraf dosis NPK mampu memberikan pengaruh nyata terhadap $\mathrm{N}-\mathrm{NO}_{3}$ tanah. 


\subsection{Kandungan $\mathrm{N}$ pada Tanaman}

\subsubsection{Serapan-N Tanaman Padi}

Hasil penelitian menunjukkan bahwa pemupukan $750 \mathrm{~kg} \mathrm{NPK} \mathrm{ha}^{-1}$ (F) berpengaruh nyata terhadap kandungan serapan- $\mathrm{N}$ Tanaman, penambahan berbagai taraf dosis NPK mampu memberikan pengaruh nyata terhadap serapan- $\mathrm{N}$ tanaman (Tabel 4).

Tabel 4 Pengaruh pupuk NPK dan genangan air terhadap serapan-N

\begin{tabular}{|c|c|c|}
\hline & Perlakuan & $\begin{array}{l}\text { Serapan- } \\
\text { N (\%) }\end{array}$ \\
\hline A & $\begin{array}{l}\text { Tanpa pupuk, digenangi } 5 \mathrm{~cm} \\
\text { (kontrol) }\end{array}$ & $0.89 \mathrm{a}$ \\
\hline B & $150 \mathrm{~kg} \mathrm{NPK} \mathrm{ha-1}$, digenangi $5 \mathrm{~cm}$ & $1.01 \mathrm{ab}$ \\
\hline $\mathrm{C}$ & $300 \mathrm{~kg} \mathrm{NPK} \mathrm{ha}^{-1}$, digenangi $5 \mathrm{~cm}$ & $1.07 \mathrm{abc}$ \\
\hline $\mathrm{D}$ & $450 \mathrm{~kg} \mathrm{NPK} \mathrm{ha}^{-1}$, digenangi $5 \mathrm{~cm}$ & $1.13 \mathrm{bc}$ \\
\hline $\mathrm{E}$ & $600 \mathrm{~kg} \mathrm{NPK} \mathrm{ha}^{-1}$, digenangi $5 \mathrm{~cm}$ & $1.26 \mathrm{c}$ \\
\hline $\mathrm{F}$ & $750 \mathrm{~kg} \mathrm{NPK} \mathrm{ha}^{-1}$, digenangi $5 \mathrm{~cm}$ & $1.63 \mathrm{~d}$ \\
\hline G & $\begin{array}{l}\text { Anjuran Setempat: } 200 \mathrm{~kg} \text { Urea } \\
\mathrm{ha}^{-1}, 75 \mathrm{~kg} \mathrm{ha-1}, 50 \mathrm{~kg} \mathrm{ha}^{-1} \text {, } \\
\text { digenangi } 5 \mathrm{~cm}\end{array}$ & $1.22 \mathrm{bc}$ \\
\hline $\mathrm{H}$ & $\begin{array}{l}450 \mathrm{~kg} \mathrm{NPK} \mathrm{ha}^{-1} \text { dengan } \\
\text { pengairan macak-macak }\end{array}$ & $1.09 \mathrm{abc}$ \\
\hline I & $\begin{array}{l}450 \text { kg NPK ha-1 dengan } \\
\text { pengairan selang } 1 \text { hari sampai } \\
\text { macak-macak }\end{array}$ & $1.07 \mathrm{abc}$ \\
\hline $\mathrm{J}$ & $\begin{array}{l}450 \mathrm{~kg} \mathrm{NPK} \mathrm{ha}^{-1} \text { dengan } \\
\text { pengairan selang } 3 \text { hari sampai } \\
\text { macak-macak }\end{array}$ & $1.03 \mathrm{ab}$ \\
\hline
\end{tabular}

Proses serapan- $\mathrm{N}$ oleh tanaman padi mengikuti konsep aktif dengan menggunakan energi dari respirasi dan secara pasif melalui ruang bebas (Baba dan Iwat, 1968). Kedua jenis mekanisme ini memerlukan energi, dimana energi yang lebih banyak dibutuhkan pada proses penyerapan hara secara aktif (Okajima, 1964 dalam Abdulrachman dkk., 2009).

\subsubsection{Kandungan $\mathrm{N}$ pada Jerami}

Hasil penelitian menunjukkan bahwa pemupukan $750 \mathrm{~kg} \mathrm{NPK} \mathrm{ha}^{-1}(\mathrm{~F})$ berpengaruh nyata terhadap kandungan $\mathrm{N}$ jerami (Tabel 5). Penambahan berbagai taraf dosis NPK mampu memberikan pengaruh nyata terhadap kandungan $\mathrm{N}$ jerami. Tanaman mengandung 1 sampai $6 \% \mathrm{~N}$ dari bobot dan $\mathrm{N}$ diserap sebagai $\mathrm{NO}_{3}-$ dan $\mathrm{NH}_{4}{ }^{+}$(Havlin, 2005). Hal ini menunjukkan kemampuan tanaman padi menyerap nitrogen di dalam tanah mempunyai batas maksimal, diperkuat dengan penelitian Triyono (2013) tanaman padi mempunyai kemampuan yang terbatas untuk menyerap unsur $\mathrm{NH}_{4}{ }^{+}$dan $\mathrm{NO}_{3}{ }^{-}$dalam pertumbuhannya.

Tabel 5 Pengaruh pupuk NPK dan genangan air terhadap kadar $\mathrm{N}$ pada jerami

\begin{tabular}{|c|c|c|}
\hline & Perlakuan & $\begin{array}{c}\mathrm{N}- \\
\text { Jerami } \\
(\%)\end{array}$ \\
\hline A & $\begin{array}{l}\text { Tanpa pupuk, digenangi } 5 \mathrm{~cm} \\
\text { (kontrol) }\end{array}$ & $1.02 \mathrm{a}$ \\
\hline B & $150 \mathrm{~kg}$ NPK ha-1, digenangi $5 \mathrm{~cm}$ & $1.25 \mathrm{~b}$ \\
\hline $\mathrm{C}$ & $300 \mathrm{~kg} \mathrm{NPK} \mathrm{ha}^{-1}$, digenangi $5 \mathrm{~cm}$ & $1.40 \mathrm{bc}$ \\
\hline $\mathrm{D}$ & $450 \mathrm{~kg} \mathrm{NPK} \mathrm{ha-1}$, digenangi $5 \mathrm{~cm}$ & $1.59 \mathrm{cde}$ \\
\hline $\mathrm{E}$ & $600 \mathrm{~kg} \mathrm{NPK} \mathrm{ha}^{-1}$, digenangi $5 \mathrm{~cm}$ & $1.74 \mathrm{de}$ \\
\hline $\mathrm{F}$ & $750 \mathrm{~kg}$ NPK ha-1, digenangi $5 \mathrm{~cm}$ & $1.80 \mathrm{e}$ \\
\hline G & $\begin{array}{l}\text { Anjuran Setempat: } 200 \mathrm{~kg} \text { Urea } \\
\mathrm{ha}^{-1}, 75 \mathrm{~kg} \mathrm{ha}^{-1}, 50 \mathrm{~kg} \mathrm{ha}^{-1} \\
\text { digenangi } 5 \mathrm{~cm}\end{array}$ & $1.54 \mathrm{~cd}$ \\
\hline $\mathrm{H}$ & $\begin{array}{l}450 \text { kg NPK ha-1 dengan } \\
\text { pengairan macak-macak }\end{array}$ & $1.54 \mathrm{~cd}$ \\
\hline I & $\begin{array}{l}450 \mathrm{~kg} \mathrm{NPK} \mathrm{ha}^{-1} \text { dengan } \\
\text { pengairan selang } 1 \text { hari sampai } \\
\text { macak-macak }\end{array}$ & $1.47 \mathrm{bc}$ \\
\hline $\mathrm{J}$ & $\begin{array}{l}450 \text { kg NPK ha }{ }^{-1} \text { dengan } \\
\text { pengairan selang } 3 \text { hari sampai } \\
\text { macak-macak }\end{array}$ & $1.41 \mathrm{bc}$ \\
\hline
\end{tabular}

\subsection{Komponen Hasil Tanaman}

Perhitungan hasil tanaman dilakukan terhadap gabah kering panen (GKP) dan gabah kering giling (GKG). Hasil per petak merupakan hasil populasi 96 rumpun tanaman yang dipanen, sehingga hasil itu merupakan interlelasi dari berbagai faktor lingkungan, pertumbuhan tanaman dan perlakuan pemupukan yang telah diberikan pada kondisi yang relatif seragam pada setiap blok pengujiannya. Tanaman padi yang tumbuh pada kondisi lingkungan tumbuh yang sama namun berbeda perlakuan (dosis 
pupuk dan pengaturan pengairan) telah menunjukkan adanya perbedaan terhadap hasil (Tabel 6).

Hasil penelitian menunjukan bahwa gabah kering panen (GKP) dengan berbagai perlakuan taraf dosis NPK 18:8:18 tidak mengalami penurunan hasil yang signifikan, akan tetapi hasil tertinggi diperoleh dengan penambahan pupuk NPK $750 \mathrm{~kg} \mathrm{ha}^{-1}$. Diduga selama pasokan air irigasi cukup untuk tanaman padi, tidak akan menurunkan hasil gabah kering panen. Hal ini sejalan dengan pendapat Setiobudi dan Fagi (1999), air yang diperlukan untuk memberikan hasil optimum harus memenuhi kebutuhan evapotranspirasi (ET) tanaman.

Tabel 6 Hasil GKP dan GKG per petak, serta persentase penyusutan

\begin{tabular}{|c|c|c|c|c|}
\hline \multicolumn{2}{|r|}{ Perlakuan } & \multirow{2}{*}{$\begin{array}{c}\begin{array}{c}\text { Gabah Kering } \\
\text { Panen }(\mathrm{kg})\end{array} \\
4,552 \mathrm{a}\end{array}$} & \multirow{2}{*}{$\begin{array}{l}\begin{array}{c}\text { Gabah Kering } \\
\text { Giling (kg) }\end{array} \\
3,244 \mathrm{a}\end{array}$} & \multirow{2}{*}{$\frac{\text { Susut }^{*} \text { (\%) }}{27,43 \mathrm{a}}$} \\
\hline A & Tanpa pupuk, digenangi $5 \mathrm{~cm}$ (kontrol) & & & \\
\hline B & $150 \mathrm{~kg} \mathrm{NPK} \mathrm{ha}^{-1}$, digenangi $5 \mathrm{~cm}$ & $5,698 \mathrm{ab}$ & $4,271 \mathrm{~b}$ & $23.60 \mathrm{a}$ \\
\hline $\mathrm{C}$ & $300 \mathrm{~kg} \mathrm{NPK} \mathrm{ha}^{-1}$, digenangi $5 \mathrm{~cm}$ & $6,638 \mathrm{bc}$ & $5,066 \mathrm{bc}$ & $23.86 \mathrm{a}$ \\
\hline $\mathrm{D}$ & $450 \mathrm{~kg} \mathrm{NPK} \mathrm{ha}^{-1}$, digenangi $5 \mathrm{~cm}$ & 8,872 def & $6,256 \mathrm{de}$ & $28.76 \mathrm{a}$ \\
\hline $\mathrm{E}$ & $600 \mathrm{~kg} \mathrm{NPK} \mathrm{ha}^{-1}$, digenangi $5 \mathrm{~cm}$ & 9,070 ef & 6,424 de & $28.78 \mathrm{a}$ \\
\hline $\mathrm{F}$ & $750 \mathrm{~kg} \mathrm{NPK} \mathrm{ha}^{-1}$, digenangi $5 \mathrm{~cm}$ & $9,248 \mathrm{f}$ & 7,025 e & $23.85 \mathrm{a}$ \\
\hline $\mathrm{G}^{*}$ & $\begin{array}{l}\text { Anjuran Setempat: } 200 \mathrm{~kg} \text { Urea ha- }{ }^{-1}, 75 \mathrm{~kg} \mathrm{ha}^{-1}, \\
50 \mathrm{~kg} \mathrm{ha}^{-1} \text {, digenangi } 5 \mathrm{~cm}\end{array}$ & 7,520 cde & $5,159 \mathrm{bc}$ & 30.59 a \\
\hline $\mathrm{H}$ & $\begin{array}{l}450 \text { kg NPK ha-1 dengan pengairan macak- } \\
\text { macak }\end{array}$ & 8,482 def & $5,897 \mathrm{~cd}$ & $29.94 \mathrm{a}$ \\
\hline I & $\begin{array}{l}450 \mathrm{~kg} \mathrm{NPK} \mathrm{ha}^{-1} \text { dengan pengairan selang } 1 \text { hari } \\
\text { sampai macak-macak }\end{array}$ & 7,458 cde & $5,225 \mathrm{bc}$ & $29.88 \mathrm{a}$ \\
\hline $\mathrm{J}$ & $\begin{array}{l}450 \mathrm{~kg} \mathrm{NPK} \mathrm{ha}^{-1} \text { dengan pengairan selang } 3 \text { hari } \\
\text { sampai macak-macak }\end{array}$ & $7,287 \mathrm{bcd}$ & $4,976 \mathrm{bc}$ & $31.15 \mathrm{a}$ \\
\hline & $\begin{aligned} \text { rangan : } & \text { Angka rerata yang diikuti huruf yang sama } \\
& \text { Duncan pada Taraf } 5 \% . \\
& { }^{*} \text { ) dosis anjuran setempat yang lazim dilakul } \\
& * * \text { dihitung dari (GKP - GKG)/GKP x } 100 \%\end{aligned}$ & lak berbeda & & Jarak Berganda \\
\hline
\end{tabular}

Tingkat penyusutan pada perlakuan dosis $450 \mathrm{~kg}$ macak-macak relatif lebih tingggi dibandingkan dengan pada perlakuan dosis $450 \mathrm{~kg}$, $600 \mathrm{~kg}$, dan $750 \mathrm{~kg}$ yang digenangi. Pengaruh dosis anjuran setempat $(200 \mathrm{~kg}+75 \mathrm{~kg}+50 \mathrm{~kg} \mathrm{KCl})$ per hektar dan digenangi terhadap GKG menunjukkan pengaruh yang sama dengan dosis $150 \mathrm{~kg}$ (B) dan $300 \mathrm{~kg}(\mathrm{C})$ digenangi dengan dosis 450 kg selang sehari macak (I) dan selang tiga hari macak-macak (J). Hal ini menunjukkan bahwa dengan dosis anjuran setempat $(\mathrm{G})$ setara dengan perlakuan $92 \mathrm{~kg} \mathrm{~N}+27 \mathrm{~kg} \mathrm{P}_{2} \mathrm{O}_{5}$ $+25 \mathrm{~kg} \mathrm{~K}_{2} \mathrm{O}$ berpengaruh sama dengan perlakuan $\mathrm{B}$, dosis $150 \mathrm{~kg} \mathrm{NPK}(27 \mathrm{~kg} \mathrm{~N}+12$ $\mathrm{kg}_{2} \mathrm{O}_{5}+27 \mathrm{~kg} \mathrm{~K}_{2} \mathrm{O}$ ) dan perlakuan C, dosis $300 \mathrm{~kg}$ NPK $\left(54 \mathrm{~kg} \mathrm{~N}+24 \mathrm{~kg} \mathrm{P}_{2} \mathrm{O}_{5}+54 \mathrm{~kg}\right.$ $\mathrm{K}_{2} \mathrm{O}$ ) yang digenangi, dan perlakuan I dan J, yaitu dosis $450 \mathrm{~kg}$ NPK yang diberi air selang sehari dan tiga sampai macak-macak. Hal ini menunjukkan bahwa genangan air pada tanah sawah berpengaruh besar terhadap hasil, selain dosis pemupukan.

\section{KESIMPULAN}

Peningkatan taraf dosis NPK 18:8:18 dengan pengaturan genangan air pada saat vegetatif maksimum memberikan pengaruh yang signifikan terhadap serapan- $\mathrm{N}$ tanaman sebesar 1,8\%, sedangkan pada saat pasca panen memberikan pengaruh yang signifikan terhadap $\mathrm{N}$-tanah yang ditunjukan oleh $\mathrm{N}$ total $0,64 \%$; $\mathrm{N}$-organik $0,26 \% ; \mathrm{N}-\mathrm{NH}_{4} 0,11 \%$; $\mathrm{N}-\mathrm{NO}_{3}$ 0,31\%.

Peningkatan taraf dosis NPK 18:8:18 dengan pengaturan genangan air memberikan pengaruh nyata terhadap pertumbuhan 
tanaman. Diperoleh dosis NPK 750 kg ha${ }^{1}$ dengan genangan $5 \mathrm{~cm}$ memberikan hasil tertinggi, namun tidak berbeda nyata dengan dosis NPK 450 dan $600 \mathrm{~kg} \mathrm{ha}^{-1}$.

\section{DAFTAR PUSTAKA}

Abdulrachman, S., H. Sembiring, Suyamto. 2009. Pemupukan Tanaman Padi. Balai Besar Penelitian Tanaman Padi. LIPI Press. Jakarta.

Arifin, M. 2000. Karakteristik Mikromorfologi Inceptisols Daerah Jatinangor. Pusat Penelitian Teknologi. Lembaga Penelitian Universitas Padjadjaran, Bandung. Laporan Penelitian No. 569/J06.14/LP/PL/1999.

Baba, I. and Iwata. 1968. "Inorganic Nutrient, Physiological Function of Mineral Element". In Mastsubayashi, $M$ et al. (Ed), Theory and Practice of Growing Rice.Tokyo, Japan Fiji Pub. p. 199-130.

Fagi, A. M. dkk. 1990. Efisiensi Pupuk PAda Tanaman Pangan. Prosiding Lokakarya NAsional Efisiensi Penggunaan Pupuk V, Cisarua, 12-13 November 1990. Hlm 145-155.

Foth, H. D. 1994. Fundamentals of Soil Science. Michigan State University. John Willey and Sons, New York.

Havlin J.L., S.L. Tisdale, J.D. Beaton and W. L. Nelson. 2005. AnIntroductionto Nutrient Management In Soil Fertility and Fertilizer. Sevent Edition.

Mulyani, M. S. 1999. Pupuk dan Cara Pemupukan.Cetakan keenam.PT. Rineka Cipta. Jakarta.

Rosmarkam, A. dan N. W. Yuwono. 2002. Ilmu Kesuburan Tanah. Kanisius.Yogyakarta.

Sutejo, M. 2002. Pupuk dan Cara Pemupukan. Rineka Cipta. Jakarta.

Tisdale, S.L., Nelson, W.L. and Beaton, J.D. 1993. Soil Fertility and Fertilizers. Macmillan Publishing Co. Inc., New York.

Triyono, Ari., Purwanto, dan Budiyono. 2013. Efisiensi penggunaan pupuk $\mathrm{n}$ untuk pengurangan kehilangan nitrat pada lahan pertanian. Prosiding Seminar Naional Pengelolaan Sumberdaya Alam dan Lingkungan. Semarang.

Winarso, S. 2005. Kesuburan Tanah Dasar Kesehatan dan Kualitas Tanah. Gava Media, Yogyakarta. 